Review

\title{
Acute Angle-Closure-A Rare but Vision-Threatening Ocular Adverse Effect of Selective Serotonin Reuptake Inhibitors
}

\author{
Michał Wiciński ${ }^{1}$, Bartlomiej J. Kaluzny ${ }^{2}$, Sławomir Liberski ${ }^{1, *}$, Daria Marczak ${ }^{1}$ and Jakub J. Kaluzny ${ }^{3}$ \\ 1 Department of Pharmacology and Therapeutics, Faculty of Medicine, Collegium Medicum in Bydgoszcz, \\ Nicolaus Copernicus University, M. Curie 9, 85-090 Bydgoszcz, Poland; wicinski4@wp.pl (M.W.); \\ dariamarczak1@wp.pl (D.M.) \\ 2 Division of Ophthalmology and Optometry, Department of Ophthalmology, Faculty of Medicine, Collegium \\ Medicum in Bydgoszcz, Nicolaus Copernicus University, M. Curie 9, 85-090 Bydgoszcz, Poland; \\ b.kaluzny@cm.umk.pl \\ 3 Department of Biology of the Visual System, Collegium Medicum in Bydgoszcz, \\ Nicolaus Copernicus University, M. Curie 9, 85-090 Bydgoszcz, Poland; jakubkaluzny@cm.umk.pl \\ * Correspondence: liberski.slawomir@gmail.coml
}

check for updates

Citation: Wiciński, M.; Kaluzny, B.J.; Liberski, S.; Marczak, D.; Kaluzny, J.J. Acute Angle-Closure-A Rare but Vision-Threatening Ocular Adverse Effect of Selective Serotonin Reuptake Inhibitors. Appl. Sci. 2021, 11, 3140. https://doi.org/10.3390/app11073140

Academic Editor: Bernhard Baumann

Received: 23 February 2021

Accepted: 30 March 2021

Published: 1 April 2021

Publisher's Note: MDPI stays neutral with regard to jurisdictional claims in published maps and institutional affiliations.

Copyright: (c) 2021 by the authors. Licensee MDPI, Basel, Switzerland. This article is an open access article distributed under the terms and conditions of the Creative Commons Attribution (CC BY) license (https:// creativecommons.org/licenses/by/ $4.0 /)$.

\begin{abstract}
Acute angle closure (AAC) is a relatively rare but serious ophthalmological condition in which early diagnosis and intraocular pressure (IOP) -lowering treatment play a key role in prognosis. The aim of this review is to present current understanding of the pathophysiology, symptoms, diagnosis, potential mechanisms as well as management of AAC associated with the use of selective serotonin reuptake inhibitors (SSRIs). In most cases, AAC in individuals receiving SSRIs occurs in the pupillary block mechanism, secondary to SSRI-induced mydriasis. However, SSRIs may also cause uveal effusion and, consequently, iridocorneal angle closure. Other factors such as impaired metabolism and elimination of SSRIs, individual genetic conditions, as well as inhibition of SSRIs metabolism due to the effects of other drugs used may also promote AAC.
\end{abstract}

Keywords: selective serotonin reuptake inhibitors; acute angle closure; antidepressants; SSRIs; AAC

\section{Introduction}

Depression is a disease with a complex etiology that affects millions of people of all ages throughout the world [1]. Currently, selective serotonin reuptake inhibitors (SSRIs) are recommended as first-line therapy in the treatment of depressive disorders [2]. High safety profiles, good tolerance, low cost of therapy [3], and similar efficacy compared to tricyclic antidepressants (TCAs) influence the increased number of patients using SSRIs. In 2016, SSRI prescriptions in England increased by more than two million compared to 2015, reaching 36 million [4]. Depression is predicted to take second place after ischemic heart disease in the global disability adjusted life years (DALYs) ranking in 2020, which will further increase SSRIs prescriptions [5].

Fluoxetine - the first SSRI-was launched in 1988, seventeen years after it was synthesized for the first time [6]. The next authorized drugs from this group were sertraline, paroxetine, fluvoxamine, citalopram, and escitalopram, respectively [5,7]. Currently, indications for the use of SSRIs beside of depression include panic disorder, social and generalized anxiety disorder, post-traumatic stress disorder, obsessive-compulsive disorders, eating disorders, chronic pain, and premenstrual stress disorders [5,8].

Acute angle closure is a serious ophthalmological condition that occurs mainly in people with risk factors, in which early diagnosis and treatment play a key role in prognosis because the lack of proper management may result in a loss of vision [9]. The most common risk factors for iridocorneal angle closure include: female gender, Asian, Indian and Inuit origin, age, positive family history of glaucoma, specific biometric structure of an eye, and so forth $[10,11]$. It has been proven that the use of antidepressants, including SSRIs, is associated with an increased risk of AAC [12,13]. This paper presents current 
understanding of the pathophysiology, symptoms, diagnosis, potential mechanisms as well as management of AAC associated with SSRIs.

\section{Pathophysiology of Acute-Angle Closure}

Acute-angle closure is an emergency condition resulting from the iridocorneal angle closure, which disturbs the proper circulation of aqueous humor from the posterior to the anterior chamber of the eye [14]. The balance between production and outflow of aqueous humor is the main mechanism regulating intraocular pressure (IOP); thus, blocking the proper drainage of aqueous humor leads to a sudden increase in IOP [11,15]. Therefore, AAC requires immediate initiation of IOP-lowering treatment to prevent the development of glaucomatous optic neuropathy (GON) [14].

AAC can occurs in two main mechanisms-pupillary block, as well as non-pupillary block [16]. Pupillary block is the most common mechanism that leads to AAC and is a common finding in individuals with anatomically predisposed eyes, e.g., with shallow anterior chamber or hypermetropia [14]. Pupil dilation called as mydriasis is a trigger factor that initiates the AAC in pupillary block mechanism by producing the iris-lens contact, resulting in disturbed outflow of aqueous humor from the posterior to the anterior chamber of the eye. Accumulation of aqueous humor generates increased pressure in the posterior chamber, which pushes the iris forward and subsequent leads to iridotrabecular contact (ITC); this displacement leads to acute angle closure. Non-pupillary mechanisms include plateau iris, ciliary block, and abnormalities in lens position [16].

\section{Clinical Presentation, Assessment, and Diagnosis}

In published case reports, AAC associated with SSRIs administration was characterized by variety clinical presentation. The most frequently presented symptoms include blurred vision, eye pain, redness or discomfort in the eye, headache, haloes around light sources, photophobia, nausea, and vomiting [17-22], It is worth emphasizing that in two reported cases, three days before the onset of AAC, heralding symptoms such as ocular pain and blurred vision were observed [21,23].

IOP measurement using a tonometer is the first choice diagnostic method; however, usually a definitive diagnosis is made by an ophthalmologist after assessing the drainage angle during gonioscopy. An anterior segment examination using a slit lamp, or with the use of ultrasound biomicroscopy (UBM), assessment of pupil reactivity to light, visual acuity test as well as fundus examination with the evaluation of optic discs are also performed [14,24]. Frequent findings in the ophthalmological examination included decreased visual acuity, corneal oedema, fixed and mid-dilated pupils, shallow anterior chamber, increased IOP (usually up to $60-80 \mathrm{mmHg}$ ), closure of the iridocorneal angle, iris plateau configuration, and cataractous changes in the lens [17,19-21,25]. In some cases, the optic disc may be swollen [14]. Moreover, in a report of AAC associated with citalopram overdose, retinal, subhyaloid, and vitreous hemorrhages were noted [26], whereas choroidal effusions and detachments were present in cases of AAC associated with uveal effusion (UE) after intake of escitalopram [18,27].

\section{Pharmacology of Selective Serotonin Reuptake Inhibitors (SSRIs)}

SSRIs exhibit a diverse ability to block serotonin reuptake, which is their main mechanism of action, as well as norepinephrine and dopamine reuptake by the drug molecule binding to the serotonin transporter (SERT), norepinephrine transporter (NET), and dopamine transporter (DAT) proteins, respectively $[15,28]$. In addition, SSRIs have an anticholinergic effect, which is most widely presented by paroxetine and is similar to, but weaker than, the anticholinergic effect of TCAs [29]. SSRIs are excreted mainly via the kidneys, but in the case of fluoxetine, sertraline, and paroxetine, some of the metabolites are also excreted in the feces [30]. The pharmacokinetic and pharmacodynamic properties of SSRIs are shown in Table 1. 
Table 1. Pharmacokinetic and pharmacodynamic properties of the SSRIs.

\begin{tabular}{|c|c|c|c|c|c|}
\hline Drug Name & $\begin{array}{c}\text { CYP 450 } \\
\text { Isoenzymes } \\
\text { In-Volved in } \\
\text { Metabolism }\end{array}$ & $\begin{array}{c}\text { Inhibited CYP } 450 \\
\text { Iso-Enzymes }\end{array}$ & $\begin{array}{c}\text { Peak Plasma } \\
\text { Concentration } \\
\text { (Hours) }\end{array}$ & ${ }_{(\%)}^{\text {Bioavailability }}{ }^{b}$ & $\begin{array}{c}\text { Protein Binding } \\
(\%)\end{array}$ \\
\hline Fluoxetine & $\begin{array}{c}2 \mathrm{D} 6,3 \mathrm{~A} 4 / 5,2 \mathrm{C} 9 \\
2 \mathrm{C} 19\end{array}$ & $\begin{array}{c}\text { 2D6, 2C19, 2C9, } \\
3 \mathrm{~A} 4 / 5,1 \mathrm{~A} 2\end{array}$ & $4-8$ & 90 & 94 \\
\hline Sertraline & $\underline{2 \mathrm{D} 6}, \frac{2 \mathrm{C} 19}{2 \mathrm{C} 9,2 \mathrm{~B} 6}, 34 / 5$ & $2 \mathrm{C} 19,2 \mathrm{D} 6^{\mathrm{a}}$ & $5-9$ & $28^{c}$ & 99 \\
\hline Paroxetine & $\underline{2 \mathrm{D} 6}, 3 \mathrm{~A} 4,1 \mathrm{~A} 2$ & 2D6 & $6-10$ & 50 & 95 \\
\hline Fluvoxamine & $\underline{2 \mathrm{D} 6}, \underline{1 \mathrm{~A} 2}$ & $\frac{2 \mathrm{C} 19}{3 \mathrm{~A} 4}, \frac{1 \mathrm{~A} 2}{/ 5,2 \mathrm{D} 6}$, & $4-8$ & 53 & 77 \\
\hline Citalopram & $2 \mathrm{C} 19,3 \mathrm{~A} 4 / 5,2 \mathrm{D} 6$ & 2D6, 2C19 & $2-4$ & 80 & 80 \\
\hline Escitalopram & $2 \mathrm{C} 19,3 \mathrm{~A} 4 / 5,2 \mathrm{D} 6$ & - & $3-5$ & 80 & 56 \\
\hline References & {$[8, \overline{31-34}]$} & [8] & {$[7,31,32]$} & {$[31,35-37]$} & {$[5,7,31]$} \\
\hline
\end{tabular}

SSRIs-selective serotonin reuptake inhibitors; highlighted-potent inhibitor or isoenzyme strongly involved in metabolism of the drug; a dose-dependent inhibitor of 2D6 subunit ( $>100 \mathrm{mg}$ high inhibitor; $<50 \mathrm{mg}$ mild inhibitor); ${ }^{\mathrm{b}}$ after oral administration; ${ }^{\mathrm{c}}$ after oral administration with a meal.

\section{SSRIs and AAC: Potential Mechanisms}

Previous studies have shown a higher incidence of acute angle closure in patients initiating SSRIs treatment $[12,13]$. Chen et al. showed a 5.8-fold greater risk of AAC in patients starting therapy with SSRIs [12]; while results obtained by Seitz et al. revealedthat among the study population, $5.6 \%$ of participants of which $1.3 \%$ were SSRIs users have received antidepressants in the year preceding the onset of AAC [13]. Drugs that cause mydriasis may induce AAC in the pupillary block mechanism, especially in anatomically predisposed eyes with occludable angles $[10,15]$. A positive correlation between the longterm use of SSRIs and the incidence of mydriasis has been observed [38,39]. To date, both animal and human studies have demonstrated that SSRIs can cause an increase in IOP. A single intravenous administration of fluoxetine increased IOP in rabbits [40]; while Farnia et al. revealed that the three-month use of sertraline at a dose of 25-100 mg by patients without eye disease is associated with a statistically significant increase in IOP and cup-to-disc ratio [41]. Furthermore, an increase in IOP $2 \mathrm{~h}$ after a single oral dose of $20 \mathrm{mg}$ of fluoxetine in 20 healthy volunteers aged 33-47 years [42], as well asin 11 individuals aged 32-70 years using SSRIs from one week to five years was shown [43]. Additionally, fluoxetine and its active metabolite, norfluoxetine, exhibit antagonistic properties at the $5-\mathrm{HT}_{2 \mathrm{C}}$ receptor, which may lead to co-stimulation of the dopaminergic and adrenergic pathways, and predispose to both-an increase in IOP and mydriasis [44]. Table 2 explains the potential mechanisms linking the use of SSRIs and the occurrence of AAC in the pupillary block mechanisms.

Besides pupillary block, AAC in individuals using SSRIs may be associated with the occurrence of UE, which leads to AAC by the anterior chamber becoming more shallow as a result of ciliary body edema and secondary forward displacement of the iris-lens diaphragm [11]. This phenomenon causes iridocorneal angle closure in the non-pupillary block mechanism. So far, two cases of bilateral AAC associated with the use of SSRIs have been described, both in patients receiving citalopram $[18,27]$. 
Table 2. Potential mechanisms linking SSRIs with the occurrence of AAC.

\begin{tabular}{|c|c|c|c|c|}
\hline Mechanism & Receptor & Stimulation/Inhibition & Localization & Effect in the Eye Tissue \\
\hline \multirow{3}{*}{ Serotonergic } & \multirow[b]{2}{*}{$5-\mathrm{HT}_{7}$} & \multirow[b]{2}{*}{ Stimulation } & \multirow{2}{*}{$\begin{array}{c}\text { Iris } \\
\text { Ciliary body } \\
\text { Iris sphincter muscle }\end{array}$} & Increase IOP \\
\hline & & & & $\begin{array}{l}\text { Mydriasis-relaxation of the iris } \\
\text { sphincter muscle }\end{array}$ \\
\hline & $5-\mathrm{HT}_{2 \mathrm{C}}$ & Inhibition & $\begin{array}{c}\text { Iris } \\
\text { Ciliary body }\end{array}$ & $\begin{array}{l}\text { Possible co-stimulation of adrenergic } \\
\text { and dopaminergic transmission in the } \\
\text { CNS }\end{array}$ \\
\hline \multirow{3}{*}{ Adrenergic } & $\alpha_{-1}$ & Stimulation & Iris dilator muscle & $\begin{array}{l}\text { Mydriasis-contraction of the iris } \\
\text { dilator muscle }\end{array}$ \\
\hline & $\alpha_{-2}$ & Stimulation & E-W nucleus & $\begin{array}{l}\text { Mydriasis-inhibition of the } \\
\text { parasympathetic innervation of the } \\
\text { iris muscles by stimulation of the } \\
\alpha_{2} \text {-adrenergic receptors located in the } \\
\text { E-W nucleus }\end{array}$ \\
\hline & $\beta_{-2}$ & Stimulation & Ciliary body & $\begin{array}{c}\text { Increase IOP-increased aqueous } \\
\text { humor production }\end{array}$ \\
\hline Dopaminergic & $\begin{array}{l}\text { D1-like } \\
\text { (D1 and D5) }\end{array}$ & Stimulation & Ciliary body & $\begin{array}{l}\text { Increase IOP-increased aqueous } \\
\text { humor production }\end{array}$ \\
\hline \multirow[b]{2}{*}{ Anticholinergic } & \multirow{2}{*}{$\begin{array}{l}\text { M1; M3; } \\
\quad \text { M5 }\end{array}$} & \multirow[b]{2}{*}{ Inhibition } & \multirow{2}{*}{$\begin{array}{l}\text { Ciliary body } \\
\text { Iris sphincter muscle }\end{array}$} & Increase IOP \\
\hline & & & & $\begin{array}{l}\text { Mydrasis-relaxation m. sphincter of } \\
\text { the pupil }\end{array}$ \\
\hline
\end{tabular}

References: [10,15,38,45]. Abbreviations: IOP, intraocular pressure; CNS, central nervous system; E-W nucleus, Edinger-Westphal nucleus.

CYP2D6, CYP2C19, and CYP3A4 polymorphisms may condition poor metabolism of SSRIs and their higher serum concentrations [46]. Concomitant use of CYP2D6 (e.g., chinidin, lewomepromazine, methadone), as well as CYP2C19 (e.g., isoniazid, proton pump inhibitors) and CYP3A4 (e.g., clarithromycin, isoniazid, verapamil) inhibitors may increase the plasma concentration of SSRIs [7,32,33,47,48]. Moreover, a high degree of binding of sertraline, paroxetine, and fluoxetine to plasma proteins can cause interactions with other highly protein-bound drugs [7,31,35,36,49] (Table 1) and can contribute to the higher risk of side-effects through increased serum concentration of SSRIs. On the other hand, due to the extensive metabolism of SSRIs in the liver, as well as their elimination via the kidneys, impaired function of these organs may reduce the elimination of SSRIs and their metabolites from the organism, which may increase the serum concentration of the drug [30].

Interestingly, nearly half of the reported cases were associated with the use of paroxetine. This observation is supported by the results of a retrospective population-based study conducted by Seitz et al. where paroxetine along with citalopram was the most frequently used SSRI in patients diagnosed with AAC [13]. Several hypotheses may explain the more frequent occurrence of AAC associated with paroxetine administration compared to other SSRIs. Paroxetine is characterized by the greatest affinity for SERT and is the most potent 5-HT reuptake inhibitor among SSRIs [50,51]. These pharmacological properties suggest that the serotonergic mechanism may be a crucial factor connecting paroxetine with a higher incidence of AAC. A similar hypothesis was formulated in relation to the occurrence of AAC associated with the use of SNRIs, a similar group of antidepressants, as all described cases are associated with the intake of venlafaxine and duloxetine, which are characterized by the highest ratio of 5-HT:NE reuptake among SNRIs [10]. Paroxetine also has a stronger effect on norepinephrine reuptake than the other SSRIs, which shows both the low value of the inhibitor constant (Ki) for NET and low half maximal inhibitory concentration $\left(\mathrm{IC}_{50}\right)$ for $\mathrm{NE}$ reuptake $[15,50]$. Stimulation of the $\alpha_{1}$-adrenergic receptors located in the pupil dilator muscle may act synergistically with the serotonergic stimulation, which 
cause mydriasis, as a result of relaxation of the pupil-sphincter muscle due to stimulation of the $5-\mathrm{HT}_{7}$ receptors [15]. Moreover, paroxetine is characterized by the highest affinity for the muscarinic receptors among SSRIs [51], due to which anticholinergic mechanism may also act synergistically with serotonergic and noradrenergic mechanisms and cause mydriasis, resulting in AAC in the pupillary block mechanism in suspected patients $[26,45]$. Furthermore, paroxetine is metabolized by the CYP2D6 subunit and is a potent inhibitor of this isoenzyme [37,52]; thus, paroxetine can inhibit its own metabolism [34].

\section{Case Reports of AAC Associated with SSRIs Administration}

Fifteen cases of AAC associated with SSRIs have been reported to date (Table 3) [17-22,25-27,53-58]. Interestingly, they include all SSRIs drugs. The case reports vary substantially in the time from the start of SSRIs intake to the occurrence of AAC, from $3 \mathrm{~h}$ [53] to 3 months [54], and in one case of AAC was associated with discontinuation syndrome [55]. Patient's age ranged from 35 to 91 years, with an average of 60 years. Only two cases of AAC associated with SSRIs intake have been reported in men [19,22]. In addition to age and gender, the predominant risk factor was hypermetropia in six cases $[18,20,21,53,54,56]$.

Table 3. Summary of case reports of AAC associated with SSRIs.

\begin{tabular}{|c|c|c|c|c|c|c|c|c|}
\hline $\begin{array}{c}\text { Drug and Daily } \\
\text { Dose }\end{array}$ & $\begin{array}{l}\text { Gender and } \\
\text { Age (Years) }\end{array}$ & Laterality & $\underset{(\mathrm{mmHg})^{b}}{\mathrm{IOP}}$ & $\begin{array}{l}\text { Risk Factors } \\
\text { for AAC }^{\mathrm{c}}\end{array}$ & $\begin{array}{l}\text { Time to Onset } \\
\text { of Symptoms } \\
\text { of AAC }\end{array}$ & BVA & FVA & Reference \\
\hline $\begin{array}{c}\text { Paroxetine } \\
-\end{array}$ & Female, 91 & Bilateral & $\begin{array}{l}\text { OD: } 70 \\
\text { OS: } 70\end{array}$ & $\begin{array}{c}\text { Nuclear } \\
\text { sclerosis }(3+)\end{array}$ & 1 day & $\begin{array}{l}\text { OD: } \mathrm{CF} \\
\text { OS: CF }\end{array}$ & $\begin{array}{l}\text { OD: } 6 / 9 \\
\text { OS: } 6 / 6\end{array}$ & [17] \\
\hline $\begin{array}{l}\text { Paroxetine } \\
20 \mathrm{mg}\end{array}$ & Female, 70 & Unilateral & $\begin{array}{l}\text { OD: } 15 \\
\text { OS: } 85\end{array}$ & - & 4 days & $\begin{array}{l}\text { OD: } 20 / 100 \\
\text { OS: } 20 / 400\end{array}$ & $\begin{array}{l}\text { OD: - } \\
\text { OS: - }\end{array}$ & [57] \\
\hline $\begin{array}{l}\text { Paroxetine } \\
\quad 20 \mathrm{mg}\end{array}$ & Female, 84 & Unilateral & $\begin{array}{l}\text { OD: } 40 \\
\text { OS: - }\end{array}$ & $\begin{array}{c}\text { Hypermetropia; } \\
\text { Narrow angle } \\
\text { (OS) }\end{array}$ & 13 days & $\begin{array}{l}\text { OD: - } \\
\text { OS: - }\end{array}$ & $\begin{array}{l}\text { OD: - } \\
\text { OS: - }\end{array}$ & [20] \\
\hline $\begin{array}{l}\text { Paroxetine } \\
20 \mathrm{mg}\end{array}$ & Female, 53 & Unilateral & $\begin{array}{l}\text { OD: }- \\
\text { OS: } 61\end{array}$ & Hypermetropia & 3 days & $\begin{array}{l}\text { OD: - } \\
\text { OS: - }\end{array}$ & $\begin{array}{l}\text { OD: - } \\
\text { OS: - }\end{array}$ & [56] \\
\hline $\begin{array}{l}\text { Paroxetine } \\
20 \mathrm{mg}\end{array}$ & Male, 40 & Unilateral & $\begin{array}{l}\text { OD: } 57 \\
\text { OS: } 16\end{array}$ & $\begin{array}{l}\text { Plateau iris } \\
\text { configuration }\end{array}$ & 2 weeks & $\begin{array}{l}\text { OD: } 6 / 6 \\
\text { OS: } 6 / 6\end{array}$ & $\begin{array}{l}\text { OD: } 6 / 6 \\
\text { OS: } 6 / 6\end{array}$ & [19] \\
\hline $\begin{array}{l}\text { Paroxetine } \\
20 \mathrm{mg}\end{array}$ & Female, 54 & Bilateral & $\begin{array}{l}\text { OD: } 57 \\
\text { OS: } 52\end{array}$ & $\begin{array}{l}\text { Plateau iris } \\
\text { configuration }\end{array}$ & 2 months & $\begin{array}{l}\text { OD: } 6 / 60 \\
\text { OS: } 6 / 60\end{array}$ & $\begin{array}{l}\text { OD: } 6 / 9 \\
\text { OS: } 6 / 9\end{array}$ & [25] \\
\hline $\begin{array}{c}\text { Paroxetine } \\
-\end{array}$ & Female, 73 & Bilateral & $\begin{array}{l}\text { OD: } 72 \\
\text { OS: } 72\end{array}$ & $\begin{array}{l}\text { Hypermetropia } \\
\text { Nuclear } \\
\text { sclerosis }\end{array}$ & $3 \mathrm{~h}$ & $\begin{array}{l}\text { OD: HM } \\
\text { OS: HM }\end{array}$ & $\begin{array}{l}\text { OD: } 6 / 60 \\
\text { OS: } 6 / 24\end{array}$ & [53] \\
\hline $\begin{array}{l}\text { Escitalopram } \\
20 \mathrm{mg}\end{array}$ & Female, 41 & Bilateral & $\begin{array}{l}\text { OD: } 47 \\
\text { OS: } 45\end{array}$ & - & 4 weeks & $\begin{array}{l}\text { OD: } 20 / 40 \\
\text { OS: } 20 / 40\end{array}$ & $\begin{array}{l}\text { OD: } 20 / 20 \\
\text { OS: } 20 / 20\end{array}$ & [27] \\
\hline $\begin{array}{l}\text { Escitalopram } \\
20 \mathrm{mg}\end{array}$ & Female, 73 & Bilateral & $\begin{array}{l}\text { OD: } 30 \\
\text { OS: } 29\end{array}$ & $\begin{array}{l}\text { Hypermetropia } \\
\text { Bilateral } \\
\text { pseudophakia }\end{array}$ & 3 days & $\begin{array}{c}\text { OD: } 3 / 10 \\
\text { OS: } 16 / 100\end{array}$ & $\begin{array}{l}\text { OD: } 10 / 10 \\
\text { OS: } 100 / 100\end{array}$ & [18] \\
\hline $\begin{array}{c}\text { Escitalopram } \\
\text { dis-continuation }\end{array}$ & Female, 45 & Bilateral & $\begin{array}{l}\text { OD: } 60 \\
\text { OS: } 60\end{array}$ & - & 1 month $^{\mathrm{d}}$ & $\begin{array}{l}\text { OD: } 3 / 10 \\
\text { OS: } 4 / 10\end{array}$ & $\begin{array}{l}\text { OD: - } \\
\text { OS: - }\end{array}$ & [55] \\
\hline Citalopram $^{\mathrm{a}}$ & Female, 54 & Unilateral & $\begin{array}{l}\text { OD: } 23 \\
\text { OS: } 60\end{array}$ & - & $\begin{array}{l}\text { Soon after } \\
\text { overdose }^{\text {a }}\end{array}$ & $\begin{array}{l}\text { OD: } 6 / 9 \\
\text { OS: HM }\end{array}$ & $\begin{array}{l}\text { OD: } 6 / 6 \\
\text { OS: } 6 / 24\end{array}$ & [26] \\
\hline $\begin{array}{l}\text { Citalopram } \\
20 \mathrm{mg}\end{array}$ & Female, 55 & Bilateral & $\begin{array}{l}\text { OD: } 56 \\
\text { OS: } 34\end{array}$ & Hypermetropia & 3 months & $\begin{array}{l}\text { OD: } 6 / 6 \\
\text { OS: } 6 / 6\end{array}$ & $\begin{array}{l}\text { OD: } 6 / 6 \\
\text { OS: } 6 / 6\end{array}$ & [54] \\
\hline $\begin{array}{l}\text { Fluoxetine } \\
20 \mathrm{mg}\end{array}$ & Male, 35 & - & $\begin{array}{l}\text { OD:- } \\
\text { OS: - }\end{array}$ & $\begin{array}{l}\text { Positive family } \\
\text { history of } \\
\text { glaucoma }\end{array}$ & 5 weeks & $\begin{array}{l}\text { OD: - } \\
\text { OS: - }\end{array}$ & $\begin{array}{l}\text { OD: - } \\
\text { OS: - }\end{array}$ & [22] \\
\hline
\end{tabular}


Table 3. Cont.

\begin{tabular}{|c|c|c|c|c|c|c|c|c|}
\hline $\begin{array}{c}\text { Drug and Daily } \\
\text { Dose }\end{array}$ & $\begin{array}{l}\text { Gender and } \\
\text { Age (Years) }\end{array}$ & Laterality & $\begin{array}{c}\text { IOP } \\
(\mathrm{mmHg})^{b}\end{array}$ & $\begin{array}{l}\text { Risk Factors } \\
\text { for AAC }\end{array}$ & $\begin{array}{c}\text { Time to Onset } \\
\text { of Symptoms } \\
\text { of AAC }\end{array}$ & BVA & FVA & Reference \\
\hline $\begin{array}{l}\text { Fluvoxamine } \\
50 \mathrm{mg}\end{array}$ & Female, 66 & Bilateral & $\begin{array}{l}\text { OD: } 52 \\
\text { OS: } 52\end{array}$ & Narrow angle & 2 months & $\begin{array}{l}\text { OD: - } \\
\text { OS: - }\end{array}$ & $\begin{array}{l}\text { OD: - } \\
\text { OS: - }\end{array}$ & [23] \\
\hline $\begin{array}{l}\text { Sertraline } \\
50 \mathrm{mg}\end{array}$ & Female, 64 & Unilateral & $\begin{array}{l}\text { OD: } 56 \\
\text { OS: - }\end{array}$ & $\begin{array}{c}\text { Hypermetropia } \\
\text { Asian origin } \\
\text { Nuclear } \\
\text { sclerosis }\end{array}$ & 3 days & $\begin{array}{l}\text { OD: } 1 / 80 \\
\text { OS: } 20 / 30\end{array}$ & $\begin{array}{l}\text { OD: } 20 / 30 \\
\text { OS: } 20 / 30\end{array}$ & [21] \\
\hline
\end{tabular}

AAC-acute angle closure; AC-anterior chamber; BVA, baseline visual acuity (visual acuity during the presentation); FVA, final visual acuity; SSRIs-selective-serotonin reuptake inhibitors; OS-left eye; OD-right eye; OU-both eyes; IOP-intraocular pressure; HM -hand movements; CF-counting fingers; ${ }^{a}$ overdose-patient may have taken $280-600 \mathrm{mg}$ of citalopram with alcohol; ${ }^{b}$ maximum measured IOP value; ${ }^{\mathrm{c}}$ other than age and gender; ${ }^{\mathrm{d}}$ symptoms occurred 1 month after discontinuation of escitalopram, which was taken for a year.

\section{Management}

As AAC is a medical emergency, its treatment should be a priority and precede other additional examinations and ancillary medical procedures. The most important approach in the eyes with acute iridocorneal angle closure is the immediate implementation of IOPlowering treatment and then reversing the mechanism of angle closure. Pharmacological therapy is based on drugs that reduce the volume of aqueous humor (e.g., intravenous mannitol), inhibit its production (intravenous acetazolamide, topically administered $\beta$ blocker-timolol or $\alpha_{2}$-agonist-apraclonidine), as well as agents that increase the outflow of aqueous humor (topical pilocarpine) [14,24]. According to the EGS guidelines, the initiation of IOP-lowering treatment with monotherapy is preferred; however, if the first drug is well tolerated but it is not possible to reduce the IOP to the patient's pre-AAC values, a second drug from a different class should be added [59]. Further, Nd:YAG laser peripheral iridotomy or rarely more invasive surgical iridectomy is performed to resolve pupillary block [14,24]. Nd:YAG laser peripheral iridotomy is the preferred method due to the lower risk of infection and better patient tolerance compared to iridectomy [60]. On the other hand, in patients with coexisting cataract and high IOP values, lens replacement surgery may be the most advantageous solution [24]. Other less frequently performed procedures include iridoplasty and trabeculectomy [60]. However, each case requires an individual assessment in order to choose the best therapeutic option [59].

Usually offending medication was discontinued when symptoms occur $[19,20,26]$. however, in one of the reported cases, the drug was maintained after psychiatric consultation and after IOP-lowering treatment supported by YAG laser iridotomies successfully continued [25]. In patients after an AAC episode, re-use of an antidepressant may be challenging. In the case of AAC secondary to the use of citalopram, switching to imipramine-a TCA-resulted in a sudden increase in IOP requiring IOP-lowering treatment; however, no disturbing symptoms were seen with mirtazapine, a tetracyclic antidepressant (TeCA) [54]. On the other hand, in the case described by Lewis et al., successful follow-up after switching to sertraline in a patient with AAC associated with paroxetine has been reported [57]. Thus, each case requires individual assessment and interdisciplinary management during the re-application of antidepressant treatment.

\section{Conclusions}

Although SSRIs are a well-tolerated group of drugs with a small percentage of adverse ocular effects, numerous reports of AAC occurrence have been published. AAC is a serious complication that should not be neglected, especially in patients with risk factors, and in the event of AAC symptoms, the patient should undergo a thorough diagnosis. The occurrence of AAC associated with the use of SSRIs may be the result of the coexistence of several mechanisms, and it is possible that the effects may be mutually reinforcing. Although performing a gonioscopic examination in all patients initiating SSRIs may be unacceptable from an economic point of view, ophthalmological consultation should be considered in 
patients with risk factors, especially hyperopic patients starting paroxetine. This procedure can reduce the number of AACs associated with the use of this class of drugs.

Author Contributions: Conceptualization, M.W., B.J.K., and S.L.; analysis of the literature, M.W., B.J.K., S.L., D.M. and J.J.K.; writing, original draft preparation, B.J.K., S.L. and D.M.; writing, review and editing, M.W., B.J.K. and J.J.K. All authors have read and agreed to the published version of the manuscript.

Funding: This work was supported by Nicolaus Copernicus University.

Institutional Review Board Statement: Not applicable.

Informed Consent Statement: Not applicable.

Data Availability Statement: Not applicable.

Conflicts of Interest: The authors declare no conflict of interest.

\section{References}

1. Brigitta, B. Pathophysiology of depression and mechanisms of treatment. Dialog. Clin. Neurosci. 2002, 4, 7-20.

2. Cipriani, A.; Purgato, M.; Furukawa, T.A.; Trespidi, C.; Imperadore, G.; Signoretti, A.; Churchill, R.; Watanabe, N.; Barbui, C. Citalopram versus other anti-depressive agents for depression. Cochrane Database Syst. Rev. 2012, 11, CD006534. [CrossRef] [PubMed]

3. Dupuy, J.M.; Ostacher, M.J.; Huffman, J.; Perlis, R.H.; Nierenberg, A.A. A critical review of pharmacotherapy for major depressive disorder. Int. J. Neuropsychopharmacol. 2011, 14, 1417-1431. [CrossRef]

4. Busby, J.; Mills, K.; Zhang, S.D.; Liberante, F.G.; Cardwell, C.R. Selective serotonin reuptake inhibitor use and breast cancer survival: A population-based cohort study. Breast Cancer Res. 2018, 20, 4. [CrossRef]

5. Mandrioli, R.; Mercolini, L.; Saracino, M.A.; Raggi, M.A. Selective serotonin reuptake inhibitors (SSRIs): Therapeutic drug monitoring and pharmacological interactions. Curr. Med. Chem. 2012, 19, 1846-1863. [CrossRef] [PubMed]

6. Wenthur, C.J.; Bennett, M.R.; Lindsley, C.W. Classics in chemical neuroscience: Fluoxetine (Prozac). ACS Chem. Neurosc. 2014, 5, 14-23. [CrossRef]

7. Sanchez, C.; Reines, E.H.; Montgomery, S.A. A comparative review of escitalopram, paroxetine, and sertraline: Are they all alike? Int. Clin. Psychopharmacol. 2014, 29, 185-196. [CrossRef]

8. Manolopoulos, V.G.; Ragia, G.; Alevizopoulos, G. Pharmacokinetic interactions of selective serotonin reuptake inhibitors with other commonly prescribed drugs in the era of pharmacogenomics. Drug Metabol. Drug Interact. 2012, 27, 19-31. [CrossRef]

9. Ah-kee, E.Y.; Egong, E.; Shafi, A.; Lim, L.T.; Yim, J.L. A review of drug-induced acute angle closure glaucoma for nonophthalmologists. Qatar Med. J. 2015, 6. [CrossRef] [PubMed]

10. Wiciński, M.; Kaluzny, B.J.; Liberski, S.; Marczak, D.; Seredyka-Burduk, M.; Pawlak-Osińska, K. Association between serotoninnorepinephrine reuptake inhibitors and acute angle closure: What is known? Surv. Ophthalmol. 2019, 64, 185-194. [CrossRef]

11. Zhang, X.; Liu, Y.; Wang, W.; Chen, S.; Li, F.; Huang, W.; Aung, T.; Wang, N. Why does acute primary angle closure happen? Potential risk factors for acute primary angle closure. Surv. Ophthalmol. 2017, 62, 635-647. [CrossRef] [PubMed]

12. Chen, H.Y.; Lin, C.L.; Kao, C.H. Long-Term Use of Selective Serotonin Reuptake Inhibitors and Risk of Glaucoma in Depression Patients. Medicine 2015, 94, e2041. [CrossRef] [PubMed]

13. Seitz, D.P.; Campbell, R.J.; Bell, C.M.; Gill, S.S.; Gruneir, A.; Herrmann, N.; Newman, A.M.; Anderson, G.; Rochon, P.A. Short-term exposure to antidepressant drugs and risk of acute angle-closure glaucoma among older adults. J. Clin. Psychopharmacol. 2012, 32, 403-407. [CrossRef] [PubMed]

14. Khazaeni, B.; Khazaeni, L. Acute Closed Angle Glaucoma. StatPearls Publishing. Available online: https://www.ncbi.nlm.nih. gov / books / NBK430857 (accessed on 23 January 2021).

15. Costagliola, C.; Parmeggiani, F.; Semeraro, F.; Sebastiani, A. Selective serotonin reuptake inhibitors: A review of its effects on intraocular pressure. Curr. Neuropharmacol. 2008, 6, 293-310. [CrossRef]

16. Sun, X.; Dai, Y.; Chen, Y.; Yu, D.Y.; Cringle, S.J.; Chen, J.; Kong, X.; Wang, X.; Jiang, C. Primary angle closure glaucoma: What we know and what we don't know. Prog. Retin. Eye Res. 2017, 57, 26-45. [CrossRef]

17. Kirwan, J.F.; Subak-Sharpe, I.; Teimory, M. Bilateral acute angle closure glaucoma after administration of paroxetine. Br. J. Ophthalmol. 1997, 81, 252-254. [CrossRef]

18. Palomero, A.A.; Infantes Molina, E.J.; López Arroquia, E.; Riveira Villalobos, L.; López Mondéjar, E.; González del Valle, F. Uveal effusion induced by escitalopram. Arch. Soc. Esp. Oftalmol. 2015, 90, 327-330. [CrossRef]

19. Browning, A.C.; Reck, A.C.; Chisholm, L.H.; Nischal, K.K. Acute angle closure glaucoma presenting in a young patient after administration of paroxetine. Eye 2000, 14, 406-408. [CrossRef]

20. Eke, T.; Bates, A.K.; Carr, S. Drug points:Acute angle closure glaucoma associated with paroxetine. BMJ 1997, 314, 1387. [CrossRef]

21. Ho, H.Y.; Kam, K.W.; Young, A.L.; Chan, L.K.; Yu, E.C.-S. Acute angle closure glaucoma after sertraline. Gen. Hosp. Psychiatry 2013, 35, 575. [CrossRef] 
22. Ahmad, S. Fluoxetine and glaucoma. Ann. Pharmacother. 1991, 25, 436. [CrossRef]

23. Jiménez-Jiménez, F.J.; Ortí-Pareja, M.; Zurdo, J.M. Aggravation of glaucoma with fluvoxamine. Ann. Pharmacother. 2001, 35, 1565-1566. [CrossRef]

24. Murray, D. Emergency management: Angle-closure glaucoma. Community Eye Health 2018, 103, 64.

25. Levy, J.; Tessler, Z.; Klemperer, I.; Shneck, M.; Lifshitz, T. Late bilateral acute angle-closure glaucoma after administration of paroxetine in a patient with plateau iris configuration. Can. J. Ophthalmol. 2004, 39, 39,780-781. [CrossRef]

26. Croos, R.; Thirumalai, S.; Hassan, S.; Da Roza Davis, J. Citalopram associated with acute angle-closure glaucoma: Case report. BMC Ophthalmol. 2005, 5, 23. [CrossRef]

27. Zelefsky, J.R.; Fine, H.F.; Rubinstein, V.J.; Hsu, I.S.; Finger, P.T. Escitalopram-induced uveal effusions and bilateral angle closure glaucoma. Am. J. Ophthalmol. 2006, 141, 1144-1147. [CrossRef]

28. Zhou, Z.; Zhen, J.; Karpowich, N.K.; Law, C.J.; Reith, M.E.A.; Wang, D.N. Antidepressant specificity of serotonin transporter suggested by three LeuT-SSRI structures. Nat. Struct. Mol. Biol. 2009, 16, 652-657. [CrossRef]

29. Fujishiro, J.; Imanishi, T.; Onozawa, K.; Tsushima, M. Comparison of the anticholinergic effects of the serotonergic antidepressants, paroxetine, fluvoxamine and clomipramine. Eur. J. Pharmacol. 2002, 454, 183-188. [CrossRef]

30. van Harten, J. Clinical pharmacokinetics of selective serotonin reuptake inhibitors. Clin. Pharmacokinet. 1993, 24, 203-220. [CrossRef]

31. Catterson, M.L.; Preskorn, S.H. Pharmacokinetics of selective serotonin reuptake inhibitors: Clinical relevance. Pharmacol. Toxicol. 1996, 78, 203-208. [CrossRef]

32. Rao, N. The clinical pharmacokinetics of escitalopram. Clin. Pharmacokinet. 2007, 46, 281-290. [CrossRef]

33. Zhou, S.; Chan, S.Y.; Goh, C.B.; Chan, E.; Duan, W.; Huang, M.; McLeod, H.L. Mechanism-based inhibition of cytochrome P450 3A4 by therapeutic drugs. Clin. Pharmacokinet. 2005, 44, 279-304. [CrossRef]

34. Laine, K.; Tybring, G.; Härtter, S.; Andersson, R.N.K.; Svensson, J.O.; Widén, J.; Bertilsson, L. Inhibition of cytochrome P4502D6 activity with paroxetine normalizes the ultrarapid metabolizer phenotype as measured by nortriptyline pharmacokinetics and the debrisoquin test. Clin. Pharmacol. Ther. 2001, 70, 327-335. [CrossRef]

35. Hemeryck, A.; Belpaire, F.M. Selective serotonin reuptake inhibitors and cytochrome P-450 mediated drug-drug interactions: An update. Curr. Drug Metab. 2002, 3, 13-37. [CrossRef]

36. MacQueen, G.; Born, L.; Steiner, M. The selective serotonin reuptake inhibitor sertraline: Its profile and use in psychiatric disorders. CNS Drug Rev. 2001, 7, 1-24. [CrossRef]

37. Hiemke, C.; Härtter, S. Pharmacokinetics of selective serotonin reuptake inhibitors. Pharmacol. Ther. 2000, 85, 11-28. [CrossRef]

38. Wang, H.Y.; Tseng, P.T.; Stubbs, B.; Carvalho, A.F.; Li, D.J.; Chen, T.Y.; Lin, P.Y.; Hsueh, Y.T.; Chen, Y.Z.; Chen, Y.W.; et al. The risk of glaucoma and serotonergic antidepressants: A systematic review and meta-analysis. J. Affect. Disord. 2018, 241, 63-70. [CrossRef] [PubMed]

39. Gündüz, G.U.; Yener, N.P.; Kılınçel, O.; Gündüz, C. Effects of selective serotonin reuptake inhibitors on intraocular pressure and anterior segment parameters in open angle eyes. Cutan. Ocul. Toxicol. 2018, 37, 36-40. [CrossRef] [PubMed]

40. Costagliola, C.; Mastropasqua, L.; Capone, D.; Verolino, M.; Ciancaglini, M.; Pisanti, N. Effect of fluoxetine on intraocular pressure in the rabbit. Exp. Eye Res. 2000, 70, 551-555. [CrossRef] [PubMed]

41. Farnia, S.; Bazyari, H.; Ahmadi, H.; Tabrizi, N.; Razavi, A.S.; Hendouei, N. Effects of three months treatment with sertraline on intraocular pressure and cup-to-disc ratio in patients with anxiety disorders/mixed anxiety and depressive disorder/major depressive disorder and without underlying eye disease. Pharm. Biomed. Res. 2017, 3, 31-37.

42. Costagliola, C.; Mastropasqua, L.; Steardo, L.; Testa, N. Fluoxetine oral administration increases intraocular pressure. Br. J. Ophthalmol. 1996, 80, 678. [CrossRef]

43. Mathew, T.; Chow, R.; Isaacs, D.; Lander, C.; McNeil, J.; Shenfield, G.; Wainwright, D. SSRIs and increased intraocular pressure. Aust. Advers. Drug React. Bull. 2001, 20, 4.

44. Millan, M.J. Serotonin 5-HT2C receptors as a target for the treatment of depressive and anxious states: Focus on novel therapeutic strategies. Therapie 2005, 60, 441-460. [CrossRef]

45. Nietgen, G.W.; Schmidt, J.; Hesse, L.; Hönemann, C.W.; Durieux, M.E. Muscarinic receptor functioning and distribution in the eye: Molecular basis and implications for clinical diagnosis and therapy. Eye 1999, 13, 285-300. [CrossRef]

46. Probst-Schendzielorz, K.; Viviani, R.; Stingl, J.C. Effect of Cytochrome P450 polymorphism on the action and metabolism of selective serotonin reuptake inhibitors. Expert Opin. Drug Metab. Toxicol. 2015, 11, 1219-1232. [CrossRef]

47. Ingelman-Sundberg, M. Genetic polymorphisms of cytochrome P450 2D6 (CYP2D6): Clinical consequences, evolutionary aspects and functional diversity. Pharm. J. 2005, 5, 6-13. [CrossRef]

48. Flaten, H.K.; Kim, H.S.; Campbell, J.; Hamilton, L.; Monte, A.A. CYP2C19 drug-drug and drug-gene interactions in ED patients. Am. J. Emerg. Med. 2016, 34, 245-249. [CrossRef]

49. Kam, P.C.A.; Chang, G.W.M. Selective serotonin reuptake inhibitors. Pharmacology and clinical implications in anesthesia and critical care medicine. Anesthesia 1997, 52, 982-988. [CrossRef]

50. Derijks, H.J.; Heerdink, E.R.; Janknegt, R.; De Koning, F.H.; Olivier, B.; Loonen, B.O.A.J.; Egberts, A.C. Visualizing pharmacological activities of antidepressants: A novel approach. Open Pharmacol. J. 2008, 2, 54-62.

51. Hyttel, J. Pharmacological characterization of selective serotonin reuptake inhibitors (SSRIs). Int. Clin. Psychopharmacol. 1994, 9, 19-26. [CrossRef] 
52. Weber, L.; Thacker, H.L. Paroxetine: A first for selective serotonin reuptake inhibitors-a new use: Approved for vasomotor symptoms in postmenopausal women. Women's Health 2014, 10, 147-154. [CrossRef]

53. Cackett, P. Bilateral angle-closure glaucoma secondary to selective serotonin reuptake inhibitor. Therapy 2006, 3, 387-388. [CrossRef]

54. Massaoutis, P.; Goh, D.; Foster, P.J. Bilateral symptomatic angle closure associated with a regular dose of citalopram, an SSRI antidepressant. Br. J. Ophthalmol. 2007, 91, 1086-1087. [CrossRef]

55. AlQuorain, S.; Alfaraj, S.; Alshahrani, M. Bilateral acute closed angle glaucoma associated with the discontinuation of escitalopram: A case report. Open Access Emerg. Med. 2016, 8, 61-65.

56. Bennett, H.G.B.; Wyllie, A.M. Paroxetine and acute angle-closure glaucoma. Eye 1999, 13, 691-692. [CrossRef]

57. Lewis, C.F.; DeQuardo, J.R.; DuBose, C.; Tardon, R. Acute angle-closure glaucoma and paroxetine. J. Clin. Psychiatry 1997, 58, 123-124. [CrossRef]

58. European Glaucoma Society Terminology and Guidelines for Glaucoma, 4th Edition-Chapter 2: Classification and terminology. Br. J. Ophthalmol. 2017, 101, 73-127. [CrossRef] [PubMed]

59. European Glaucoma Society Terminology and Guidelines for Glaucoma, 4th Edition—Chapter 3: Treatment principles and options. Br. J. Ophthalmol. 2017, 101, 130-195. [CrossRef]

60. Reddy, A.; Johnson, S.M. Iridectomy or iridotomy for preventing angle-closure glaucoma. Cochrane Database Syst. Rev. 2007, 4, CD006783. [CrossRef] 